\title{
ADIPOSE TISSUE, INFLAMMATION AND CARDIOVASCULAR DISEASE
}

\author{
Dimas Ikeoka ${ }^{1 *}$, Julia K. MadeR ${ }^{2}$, Thomas R. PiebeR ${ }^{3}$
}

Trabalho realizado na Division of Endocrinology and Nuclear Medicine, Medical University of Graz

\author{
*Correspondência: \\ Medical University of Graz \\ Department of Internal \\ Medicine \\ Division of Endocrinology and \\ Nuclear Medicine \\ Auenbruggerplatz 15, A-8036 \\ Graz, Austria
}

\begin{abstract}
SUMMARY
Obesity has become a very frequent condition with important consequences for the health of affected individuals. Current evidence shows that the excess of adipose tissue as observed in obesity is responsible for secreting inflammatory mediators in a deregulated manner, thus inducing a chronic state of systemic low-grade inflammation that underlies the metabolic and cardiovascular outcomes in these populations. This article reviews the state of the art regarding mediators produced in the adipose tissue, their roles in the pathophysiology of obesity-associated insulin resistance and diabetes, and finally, tries to build a bridge between these mechanistically oriented insights and clinical practice.
\end{abstract}

KEY WORDS: Inflammation.Obesity.Insulin resistance. Metabolic Syndrome X.Cardiovascular Diseases. Diabetes Mellitus. Type 2.

\section{INTRODUCTION}

Recent epidemiological studies report an alarming increase in the prevalence of obesity in modern societies ${ }^{(1-6)}$. Visceral and subcutaneous adipose tissue accumulation, mainly as a result of poor nutritional habits and largely associated with lack of physical activity, is clearly responsible for increased body weight, which in turn underlies an elevated risk of diabetes and cardiovascular complications (7-12). Although it seems that individuals with higher body mass index (BMI) are prone to cardiovascular events, reasons for this connection are not entirely clear. Over the last two decades some mechanisms of disease, especially in association with recently described functions of the adipose tissue were discovered, shedding light on the pathophysiology of obesity-associated cardiovascular diseases.

Initially, important observations demonstrated that fat metabolism is importantly modified by excess body weight. Non-esterified fatty acids (NEFA) delivered from adipose tissue by enzymatic cleavage of triglycerides are found at increased concentrations in blood of obese individuals and associated with a higher risk of developing type-2-diabetes $(T 2 D M){ }^{(13,14)}$. In addition, experimental elevations of NEFA have been shown to induce insulin resistance in animal models and humans ${ }^{(15)}$. More recently, a very active secretory function of adipose tissue was disclosed. Adipocytes, infiltrating macrophages and mesenchimal cells produce a number of cytokines, hormones and other substances with distinct effects on the control of glucose tolerance and vascular function. These substances secreted in the adipose tissue were collectively denominated adipokines ${ }^{(7,}$, 9, 16-19).

Deregulated production of adipokines in adipose tissue seems to determine a state of low-grade chronic inflammation that plays a role in the generation of insulin resistance and vascular complications of obesity. It has been consistently observed that inflammatory pathways activated in type-2diabetic and obese subjects appear in close association with a cluster of distinct clinical manifestations, including high blood pressure, hypertriglyceridemia, low HDL-cholesterol, and endothelial dysfunction, which were grouped under the common denomination of metabolic syndrome (MS) (20-23). In addition to the cardiovascular consequences of obesity, the chronic state of low-grade inflammation was also linked to a disturbed function of hepatocytes, which resulted in the recently described forms of hepatic disease related to obesity, namely the nonalcoholic steatohepatitis (NASH) and the nonalcoholic fatty liver disease (NAFLD) ${ }^{(24) .}$

On the grounds of the deregulated physiology of adipose tissue, investigation of the functions of distinct cytokines may provide new comprehension of the pathophysiology of T2DM and cardiovascular diseases, as well as specific targets for future therapeutic approaches. Furthermore, diagnostic tools based on knowledge about the complex interactions between metabolic and inflammatory pathways, might indicate more precisely patients under increased risk, prompting physicians to offer differentiated and optimized therapeutic approaches. This article reviews some of the most important and well described aspects of low-grade chronic inflammation, cytokines and other mediators secreted in adipose tissue within the context of T2DM, MS and obesity, in an attempt to

1. Ph.D. - Fellow Scientist of the Division of Endocrinology and Nuclear Medicine, Medical University of Graz

2. MD. - Fellow Scientist of the Division of Endocrinology and Nuclear Medicine, Medical University of Graz

3. Prof. MD. - Head of the Division of Endocrinology and Nuclear Medicine, Medical University of Graz 
correlate these pathophysiological insights with the clinical consequences to metabolism and to the cardiovascular system. It is not intended to exhaustively review all mediators in this specific regard, therefore the reader is referred to other more detailed information on the specific topics.

\section{Adipose tissue as an endocrine organ}

At the microscopic level, two types of adipocytes can be distinguished, namely the brown adipocytes that have a high intra-cellular content of large mitochondria, and the white adipocytes, with far less mitochondrial content. Similarly, two different types of adipose tissue can be identified in mammals according to their macroscopic aspect: brown adipose tissue (BAT), which contains predominantly brown adipocytes and a pattern of a largely distributed capillary network and white adipose tissue (WAT) that contains mostly white adipocytes and is poorly vascularized. The main function described for BAT is to maintain body temperature, especially in childhood, although some publications have raised the possibility of an active participation in the pathophysiology of the metabolic complications of obesity $(25,26)$. WAT is the largest fraction of adipose tissue and is responsible for triglyceride accumulation and adipokine secretion. WAT can be further divided, according to the body distribution, into visceral adipose tissue (VAT) and subcutaneous adipose tissue (SAT) ${ }^{(27)}$. The relative importance of each sub-type of WAT in producing low-grade chronic inflammation and insulin resistance is under dispute in current literature ${ }^{(8,28,29)}$, although strong clinical evidence indicates that central (android) obesity, a condition where adipose tissue preferentially accumulates in the peri-visceral region, is in general more related to higher cardiovascular risk and the features of MS than the peripheral (gynecoid) type (11).

The first and best described physiological function of adipose tissue was as an energy depot. As mentioned before, WAT stores triglycerides within the large intra-cellular vesicles of adipocytes during the post-prandial phase of digestion and releases them after enzymatic cleavage by lipoprotein lipase (LPL), in the form of fatty acids and glycerol during periods of starvation. Initial reports of the secretory and endocrine functions of adipose tissue come from estrogen conversion, a very important step to produce the activated sexual hormone ${ }^{(30,31)}$. Later on, tumor necrosis factor-alpha (TNF$\alpha$ ), a cytokine with very important functions in the stimulation of inflammatory cells and in the immune system, was described as a product of adipose tissue secretion, playing a possible role in the development of insulin resistance in humans ${ }^{(17)}$. During subsequent years, following this primary description of a cytokine produced in adipose tissue, a number of other molecules were found and studied, most of them involved in the regulation of energy metabolism and control of appetite. Cytokines, small proteins with previously well defined functions in the regulation of the immune system, constitute the largest group of biologically active substances produced in adipose tissue. Other adipokines belong to different molecular families, such as chemokines and growth factors. A list of currently recognized adipokines is provided in table 1 , together with their

Table 1 - Most important adipokines and their roles in metabolism.

\begin{tabular}{lc}
\hline Adipokines & Function, characteristics, target tissues, effects on metabolism and cardiovascular system \\
\hline TNF- $\alpha$ & Mainly produced by inflammatory cells and lymphocytes, but also by adipocytes and stromal cells. Induce insulin resistance by inhibi- \\
IL-6 & ting IRS-1 phosphorylation and GLUT-4 expression. \\
Produced by inflammatory cells, lymphocytes and adipocytes. Inhibit gene transcription of IRS-1, GLUT-4 and PPAR- $-\gamma$. Blood levels \\
correlate with body weight.
\end{tabular}

IL-1 $\beta$

Important roles in the genesis of atherosclerosis and its acute manifestations.

IL-1 $\beta$ RA

Abundantly secreted in adipose tissue, competes with IL-1 $\beta$ at the receptor site, acting as an anti-inflammatory mediator. Elevated concentrations are found in blood of obese subjects. Exerts specific roles in adipocyte differentiation, fat metabolism and insulin sensitivity.

IL-8

IL-10

MCP-1

Adiponectin

Leptin

Resistin

Visfatin
Mainly produced by macrophages, has important chemoattractant properties. Circulating levels are increased by hyperinsulinemia and hyperglycemia.

Anti-inflammatory cytokine secreted mainly by lymphocytes and inflammatory cells. Is expressed in adipose tissue and promotes insulin sensitivity in different tissues. Protects against IL-6-induced insulin resistance.

Chemokine expressed and secreted by adipocytes. Serum concentrations are high in obese subjects. Induces insulin resistance and liver steatosis in mice. Adipocyte expression of MCP-1 is increased by TNF- $\alpha$

Secreted mainly by adipocytes. Circulating levels are reduced in obesity and positively correlate with insulin sensitivity. Suppressed by TNF- $\alpha$, IL-6, $\beta$-adrenergic stimulus and glucocorticoids. Induces tyrosine phosphorylation of the insulin receptor and reduces gluconeogenesis in the liver. Increases fatty acid oxidation in the liver.

Stimulated by insulin, TNF- $\alpha$, glucocorticoids; suppressed by catecholamines via $\beta 2$ and $\beta 3$ receptors. Exclusively synthesized and secreted by adipocytes. Inhibits appetite and reduces food consumption. Is found at elevated levels in obese subjects. Influences the reproductive functions. Reduces insulin-mediated glucose uptake.

Elevated in plasma of obese individuals. Induces endothelial dysfunction and can be involved in the genesis of atherosclerosis. 
most important features and regulatory pathways.

In a quantitative comparison, adiponectin, plasminogen activator inhibitor-1 (PAI-1) and heparin binding endothelial growth factor-like growth factor are the most abundantly expressed genes in adipose tissue. Plasma concentrations of PAI- 1 seem to strictly correlate with the adipose tissue expression, suggesting adipose tissue as the primary source of this specific molecule (32). A variety of genes encoding for proteins with important functions in the control of the immune system, growth factors and other molecules are also expressed differently in adipose tissue of obese and non-obese individuals, and most of them are still to be investigated in detail $(28,33)$.

\section{Adipokines, insulin resistance and type 2 diabetes}

Interleukin-6 (IL-6) and TNF- $\alpha$ are among the best known and well investigated cytokines produced in adipose tissue. The expression of TNF- $\alpha$ in adipose tissue from both humans and rodents is increased in conditions of obesity and closely correlates with hyperinsulinemia ${ }^{(9,34)}$. Moreover, weight loss promotes a significant decrease in the TNF- $\alpha$ expression in adipose tissue ${ }^{(34)}$. It could also be demonstrated that TNF- $\alpha$ inhibits insulin-dependent glucose uptake in human cultured adipocytes, which correlates with a significant reduction of the density of insulin-regulated glucose transporter-4 (GLUT-4) protein at the cellular membrane ${ }^{(35,36)}$. In addition, insulin receptor substrate-1 (IRS-1) phosphorylation via c-jun $\mathrm{N}$-terminal kinase (JNK) is reduced by TNF- $\alpha$, leading to suppression of insulin signaling downstream ${ }^{(17)}$. Levels of IL- 6 in blood correlate positively with overweight ${ }^{(37)}$ and negatively with insulin sensitivity ${ }^{(38)}$. Weight loss induced by very low-caloric diet reduces IL-6 levels and improves insulin sensitivity in obese subjects ${ }^{(39)}$. IL-6 concentrations in subcutaneous adipose tissue are increased by local insulin infusion ${ }^{(40)}$. At cellular level, IL-6 has demonstrated that it exerts inhibitory effects on gene transcription of IRS-1, GLUT-4, and peroxisome proliferator-activated receptor gamma (PPAR-gamma). These mechanisms are the most likely explanation for the glucose intolerance induction effect ${ }^{(41},{ }^{42)}$. Both TNF- $\alpha$ and IL-6 have demonstrated lipolytic properties and promote lipid release from adipocytes ${ }^{(36,43)}$. TNF- $\alpha$ and IL- 6 are both secreted by adipocytes, although only IL-6 seems to be released from adipose tissue to the systemic circulation ${ }^{(44)}$. The concentrations of TNF- $\alpha$, IL-6, IL-1 beta and IL-8 in adipose tissue seem to be unrelated to their systemic concentrations, acting more likely as paracrine mediators $(40,44)$.

Adiponectin is a protein secreted by adipocytes which retains significant homology with collagen $\mathrm{X}$ and VII, as well as with the complement factor $\mathrm{C} 1 \mathrm{q}^{(45)}$. It is found at low concentrations in plasma of obese subjects, negatively correlating with body mass index and with central (visceral) adiposity $(46,47)$. Moreover, plasma levels of adiponectin strongly correlate with insulin sensitivity and an enhanced insulin receptor tyrosine phosphorylation, a key pathway in the insulin-induced glucose uptake $^{(48)}$. In addition, adiponectin exerts a suppressive effect on gluconeogenesis ${ }^{(49)}$ and increases fatty acid oxidation, reducing triglyceride accumulation in the liver, which also contributes to improve glucose tolerance ${ }^{(50)}$. Individuals at lower serum levels of adiponectin are subject to endothelial dysfunction, the primary pathophysiological manifestation of atherosclerosis ${ }^{(51)}$. Moreover, they are exposed to a higher risk of diabetes and its vascular complications ${ }^{(52,53)}$, present an increased severity of coronary artery disease and also higher degrees of plaque calcification (54).

Several other cytokines, such as IL-1 beta, IL-1 beta receptor antagonist (IL-1 betaRA), IL-8, IL-10, and MCP-1, to cite only the most important ones, have shown to be synthesized in adipose tissue $(7,29,33,55,56)$. IL-1 beta is a cytokine produced mainly by inflammatory (monocytes, macrophages and foam cells) and endothelial cells, playing a very important role in the pathophysiology of atherosclerosis ${ }^{(57,58)}$. It was further demonstrated that IL-1 beta induces cytotoxic effects in pancreatic beta-cells, being possibly involved in the pancreatic beta-cell insufficiency as seen mainly in type- 1 but also in the late phases of type-2diabetes ${ }^{(59)}$. The expression of IL-1 beta in adipose tissue is of minor importance in quantitative terms, except under conditions of acute inflammation ${ }^{(40)}$. On the other hand, adipose tissue is a major source of IL-1 betaRA, a cytokine that functions as a competitive inhibitor of IL-1 beta at the receptor site. This cytokine belongs to the IL-1 family and acts as a counter-regulatory mediator of inflammation in different diseases, such as sepsis and autoimmune disorders $(60,61)$. In the obese it is found at elevated concentrations in blood and has demonstrated specific roles in the control of adipocyte differentiation, fat metabolism and insulin sensitivity (62-64).

Interleukin-8 can be better classified as a chemokine (IL-8 or CXCL-8), given its predominant chemoattractant properties. It is produced mainly by macrophages and can be used as a clinical predictor of coronary artery disease ${ }^{(65)}$. Moreover, the IL-8 levels in blood are increased by both hyperinsulinemia and hyperglycemia, indicating a possible participation of $\mathrm{IL}-8$ in carbohydrate metabolism ${ }^{(66)}$.

Monocyte chemoattractant protein-1 (MCP-1) is another chemokine that has shown important metabolic effects. It is expressed and secreted by adipose tissue of obese individuals and lean controls at similar levels, but serum concentrations are increased with obesity ${ }^{(67)}$. Different studies could demonstrate that MCP-1 contributes to increase the infiltration of inflammatory cells, induces insulin resistance and liver steatosis in animal models ${ }^{(68-70)}$. The expression of MCP-1 by adipocytes is significantly increased by the presence of TNF- $\alpha$ in cell cultures (69). Despite these evidences, the role of MCP-1 in the pathophysiology of human type-2-diabetes is not completely determined.

Interleukin-10 is another cytokine synthesized by immune and inflammatory cells, and also by adipocytes ${ }^{(71)}$. The expression of IL-10 in the adipose tissue is increased in obese humans and rodents ${ }^{(71,72)}$. Since this is a cytokine with anti-inflammatory activity, its over-expression in adipose tissue may represent a counter-regulatory mechanism. Indeed, IL-10 is positively associated with insulin sensitivity and has a protective effect in skeletal muscle against IL-6-induced insulin resistance ${ }^{(73)}$. Additionally, in adipocyte cell cultures, IL-10 expression is down-regulated by palmitic acid, an 18-carbon non-esterified fatty acid that is found at elevated concentrations in plasma of obese individuals (74).

Resistin and visfatin are other recently discovered biologically active molecules produced by adipose tissue, but their roles are not thoroughly determined yet. Resistin levels are elevated in blood of obese subjects and also in patients with acute severe inflammatory diseases; resistin induces endothelial dysfunction and might be involved in the genesis of atherosclerotic disease ${ }^{(75)}$. Visfatin is 
also secreted by adipose tissue, mainly visceral fat, and presents insulin-like effects, reducing blood glucose concentrations (76).

In summary, it can be postulated that over-secretion of inflammatory cytokines both systemically and in the adipose tissue contributes to generate insulin resistance, a key factor in the pathophysiology of T2DM. The contribution of anti-inflammatory cytokines offering protective effects against insulin resistance and diabetes is difficult to summarize, given that from one side adiponectin, the major anti-inflammatory and anti-diabetic cytokine is up-regulated and, on the other, IL-10 seems to be depressed in conditions of obesity. Therefore, obesity can well be characterized as a condition where adipose tissue production of cytokines is deregulated, since a marked excess of pro-inflammatory cytokines is one of its most remarkable features. Pro-inflammatory effects prevail against the counter-regulatory mediators, leading obese individuals to severe metabolic and vascular complications. Adipokines can be measured in blood and might indicate increased risk of diabetes and cardiovascular complications when found at elevated concentrations. However, a few cytokines exert their effects at a very short distance in the adipose tissue, in a paracrine or autocrine manner and therefore are not useful as outcome predictors for evaluation in clinical practice.

\section{The control of appetite and body weight by adipokines}

Some agents produced by adipose tissue are not primarily involved in the genesis of vascular damage, but instead, are responsible for weight excess by controlling food ingestion. Leptin is a $16 \mathrm{kDa}$ glycoprotein expressed and secreted almost exclusively in adipose tissue ${ }^{(77)}$. Leptin is well described both in rodents and humans and produces an important action at hypothalamic level, promoting satiety and inhibiting ingestion of food (77-79). The phenotype of congenitally leptin deficient individuals is characterized by normal body weight at birth, but hyperphagia and food-seeking behavior is promptly manifest, promoting a rapid fat accumulation and increase of body weight already within the first weeks or months of life ${ }^{(78)}$. Leptin is therefore essential to the control of satiety at the level of the central nervous system, contributing to regulation of body weight in humans. Obese and overweight individuals present leptin resistance which is characterized by elevated levels of circulating leptin and significant weight loss when supplemental recombinant leptin is provided (37, 80-82). In addition, leptin has demonstrated inhibitory effects on insulin-mediated glucose uptake in muscle and adipose cells, which seems to be determined by reduced insulin signaling at the level of the insulin receptor substrate-1 phosphorylation, thus contributing to regulate energy metabolism in a paracrine and autocrine manner. Such effects have raised the hypothesis that elevated levels of leptin in circulation of obese individuals could at least partially explain the mechanisms of insulin resistance.

\section{Non-esterified fatty acids, glucose metabolism and inflammation}

Non-esterified fatty acids (NEFA) have the property to induce insulin resistance which was observed both in humans and animal models, as cited above. Indeed, recent evidence has demonstrated that NEFA activate important intracellular signaling molecules, such as $\mathrm{C}$-jun $\mathrm{N}$-terminal kinase and nuclear factor kappa-B in mice cultured adipocytes which are both mechanistically implicated in inflammation and also in the reduction of insulin-stimulated glucose uptake ${ }^{(17,83)}$. More recently, NEFA have also demonstrated to produce pro-inflammatory actions, contributing to increase secretion of inflammatory cytokines and reduce anti-inflammatory cytokines in cultured adipocytes ${ }^{(74)}$. However, contribution of NEFA for in the induction of cytokines in vivo and the relevance of such mechanism in humans remains to be confirmed.

\section{The role of adipokines in the development of cardiovascular diseases}

Different inflammatory mediators are implicated in the induction of endothelial dysfunction, plaque formation and plaque instability which constitute the main mechanisms of vascular damage in atherosclerotic disease. The individual roles of different cytokines in atherosclerosis are extensively described by previous publications and will not be considered in detail in the present review ${ }^{(84,85)}$. Of note, the endothelial layer of arteries may display a pathological behavior when stimulated by specific cytokines as well as produce inflammatory mediators, such as IL-1 beta, IL-6, IL-8, TNF- $\alpha$ and MCP-1, that have important actions on the initiation and amplification of the inflammatory process within the atherosclerotic plaque (85-88). The combined effect of the interaction between these cytokines and the vascular wall can be summarized as an increased leukocyte and monocyte recruitment and activation in the vessel wall, disturbance of the nitric-oxide mediated mechanisms for local regulation of blood flow, promotion of smooth muscle cell migration and differentiation, and induction of a prothrombotic state ${ }^{(85)}$. These pathophysiological features are important in the first phases of plaque formation and also in the induction of plaque rupture and thrombosis during the acute vascular events.

Myocardial dysfunction and heart failure are other important clinical features of obesity. Cytokines, as well as other inflammatory mediators (soluble IL-6-receptor, IL-6 and C-reactive protein [CRP]) might also be involved in the generation of systolic and diastolic ventricular dysfunction, independent of coronary obstruction, as indicated by echocardiography in normotensive obese individuals ${ }^{(22)}$.

\section{Conclusions - Risk stratification and therapeutic approaches}

It seems clear that obesity, insulin resistance, low grade chronic inflammation and atherosclerosis are frequently closely correlated, both in terms of their pathophysiological mechanisms and also regarding their clinical manifestations. In order to prevent cardiovascular and metabolic complications, weight loss is currently the chosen therapeutic strategy for obese individuals. Nonetheless, except for the recently applied bariatric surgery techniques, significant weight loss is difficult to achieve in routine clinical practice ${ }^{(89,90)}$ and, furthermore, the effects of deregulated adipokine secretion in adipose tissue are extended to non obese individuals presenting with MS $(16,21,84)$. There is a current and widespread expectation that new drugs with selective actions on the different adipokines and their sites of action in different tissues will be developed. Ideally, such drugs should be able to down-regulate the pro-inflammatory milieu as observed in patients with MS and obesity, especially when body weight reduction is required but not achievable in the short term, or even when it is not required at all. Drugs from the thiazolidinedione family exhibit some of these features, namely the modulation of TNF- $\alpha$ and leptin expression in adipose tissue $(52,53,65,91)$. 
Now, while waiting for the development of these new agents, clinicians must be encouraged to stimulate the practice of exercise and indicate specific and target-oriented strategies for weight reduction to patients with high $\mathrm{BMI}$, and especially in those individuals with a detected, augmented cardiovascular risk or, evidence of insulin resistance. Bariatric surgery should be carefully considered for all patients at elevated cardiovascular risk. In addition, to the routine parameters to be measured, and in order to better estimate the actual risk of these patients, measurement of markers such as high sensitive C-reactive protein as an indicator of low-grade chronic inflammation, and perhaps in the future other specific cytokines may be helpful in clinical practice.

\section{Resumo}

\section{TECIDO ADIPOSO, INFLAMAÇÃo E DOENÇA CARDIOVASCULAR}

Obesidade é uma condição frequente com importantes consequencias para a saúde dos indivíduos acometidos. Evidência atual tem demonstrado que o excesso de tecido adiposo, tal qual observado na obesidade, é responsável pela secreção de mediadores inflamatorio de forma descontrolada, levando assim a um estado crônico de inflamação sistêmica de baixa intensidade que está por trás das consequências metabólicas e cardiovasculares em tais populações. Este artigo revisa o estado da arte referente aos mediadores produzidos no tecido adiposo, seus papeis na fisiopatologia da resistência insulínica relacionada à obesidade e ao diabetes, e por fim, tenta estabelecer uma ponte de ligação entre estes conceitos mecanisticamente orientados e a prática clínica. [Rev Assoc Med Bras 2010; 56(1): 116-21]

UnITERMOS: Inflamação. Obesidade. Resistência à Insulina.Síndrome X Metabólica.Doenças cardiovasculares.Diabetes Mellitus Tipo 2.

\section{References}

1. Branca F, Nikogosian H, Lobstein T. The challenge of obesity in the WHO European Region and the strategies for response. In: Branca F, Haik Nikogosian H, Lobstein T, editors. Data WLCiP. Copenhagen: WHO Regional Office for Europe; 2007

2. Elizabeth DW, Baur LA. Adolescent obesity: making a difference to the epidemic. Int J Adolesc Med Health. 2007;19(3):235-43.

3. Flegal KM, Carroll MD, Kuczmarski RJ, Johnson CL. Overweight and obesity in the United States: prevalence and trends, 1960-1994. Int J Obes Relat Metab Disord. 1998;22(1):39-47.

4. Jackson-Leach R, Lobstein T. Estimated burden of paediatric obesity and co-morbidities in Europe. Part 1. The increase in the prevalence of child obesity in Europe is itself increasing. Int J Pediatr Obes. 2006;1(1):26-32.

5. Knai C, Suhrcke M, Lobstein T. Obesity in eastern Europe: an overview of its health and economic implications. Econ Hum Biol. 2007;5(3):392-408.

6. Swinburn BA. The obesity epidemic in Australia: can public health interventions work? Asia Pac J Clin Nutr. 2003;12(Suppl):S7.

7. Bastard JP, Maachi M, Lagathu C, Kim MJ, Caron M, Vidal H, et al. Recent advances in the relationship between obesity, inflammation, and insulin resistance. Eur Cytokine Netw. 2006;17(1):4-12.

8. Dolinkova M, Dostalova I, Lacinova Z, Michalsky D, Haluzikova D, Mraz M, et al. The endocrine profile of subcutaneous and visceral adipose tissue of obese patients. Mol Cell Endocrinol. 2008;291(1-2):63-70.

9. Hotamisligil GS, Arner P, Caro JF, Atkinson RL, Spiegelman BM. Increased adipose tissue expression of tumor necrosis factor-alpha in human obesity and insulin resistance. J Clin Invest. 1995;95(5):2409-15.

10. Mathieu P, Pibarot P, Larose E, Poirier P, Marette A, Despres JP. Visceral obesity and the heart. Int J Biochem Cell Biol. 2008;40(5):821-36.

11. Wajchenberg BL. Subcutaneous and visceral adipose tissue: their relation to the metabolic syndrome. Endocr Rev. 2000;21(6):697-738.

12. Wellen KE, Hotamisligil GS. Obesity-induced inflammatory changes in adipose tissue. J Clin Invest. 2003;112(12):1785-8.
13. Charles MA, Eschwege E, Thibult N, Claude JR, Warnet JM, Rosselin GE, et al. The role of non-esterified fatty acids in the deterioration of glucose tolerance in Caucasian subjects: results of the Paris Prospective Study. Diabetologia. 1997;40(9):1101-6.

14. Gordon ES. Non-esterified fatty acids in the blood of obese and lean subjects. Am J Clin Nutr. 1960;8(7)740-7.

15. Roden M, Price TB, Perseghin G, Petersen KF, Rothman DL, Cline GW, et al. Mechanism of free fatty acid-induced insulin resistance in humans. J Clin Invest. 1996;97(12):2859-65

16. Bergman RN, Van Citters GW, Mittelman SD, Dea MK, Hamilton-Wessler M, Kim SP, et al. Central role of the adipocyte in the metabolic syndrome. J Invest Med. 2001;49(1):119-26.

17. Hotamisligil GS, Peraldi P, Budavari A, Ellis R, White MF, Spiegelman BM. IRS1 -mediated inhibition of insulin receptor tyrosine kinase activity in TNF-alphaand obesity-induced insulin resistance. Science. 1996;271(5249):665-8.

18. Mohamed-Ali V, Pinkney JH, Coppack SW. Adipose tissue as an endocrine and paracrine organ. Int J Obes Relat Metab Disord. 1998;22(12):1145-58.

19. Senn JJ, Klover PJ, Nowak IA, Mooney RA. Interleukin-6 induces cellular insulin resistance in hepatocytes. Diabetes. 2002;51(12):3391-9.

20. Reaven GM. Banting lecture 1988. Role of insulin resistance in human disease. Diabetes. 1988;37(12):1595-607.

21. Day C. Metabolic syndrome, or what you will: definitions and epidemiology. Diabetes Vasc Dis Res. 2007;4(1):32-8.

22. Malavazos AE, Corsi MM, Ermetici F, Coman C, Sardanelli F, Rossi A, et al. Proinflammatory cytokines and cardiac abnormalities in uncomplicated obesity: relationship with abdominal fat deposition. Nutr Metab Cardiovasc Dis. 2007; 17(4):294-302.

23. Silveira IL, Maranhao TM, Azevedo GD. Metabolic syndrome in postmenopausal women: higher prevalence in the Northeastern Region of Brazil than in other Latin American countries and the influence of obesity and socioeconomic factors. Climacteric. 2007;10(5):438-9; author reply 40.

24. Clark JM. The epidemiology of nonalcoholic fatty liver disease in adults. J Clin Gastroenterol. 2006;40(Suppl 1):S5-10.

25. Cannon B, Nedergaard J. Brown adipose tissue: function and physiological significance. Physiol Rev. 2004;84(1):277-359.

26. Himms-Hagen J. Does brown adipose tissue (BAT) have a role in the physiology or treatment of human obesity? Rev Endocr Metab Disord. $2001 ; 2(4): 395-401$

27. Avram AS, Avram MM, James WD. Subcutaneous fat in normal and diseased states: 2. Anatomy and physiology of white and brown adipose tissue. J Am Acad Dermatol. 2005;53(4):671-83.

28. Gomez-Ambrosi J, Catalan V, Diez-Caballero A, Martinez-Cruz LA, Gil MJ, Garcia-Foncillas J, et al. Gene expression profile of omental adipose tissue in human obesity. FASEB J. 2004;18(1):215-7.

29. Murdolo G, Herder C, Wang Z, Rose B, Schmelz M, Jansson PA. In situ profiling of adipokines in subcutaneous microdialysates from lean and obese individuals. Am J Physiol Endocrinol Metab. 2008;295(5):E1095-105.

30. Grodin JM, Siiteri PK, MacDonald PC. Source of estrogen production in postmenopausal women. J Clin Endocrinol Metab. 1973;36(2):207-14.

31. MacDonald PC, Rombaut RP, Siiteri PK. Plasma precursors of estrogen. I. Extent of conversion of plasma delta-4-androstenedione to estrone in normal males and nonpregnant normal, castrate and adrenalectomized females. J Clin Endocrinol Metab. 1967;27(8):1103-11.

32. Alessi MC, Juhan-Vague I. PAI-1 and the metabolic syndrome: links, causes, and consequences. Arterioscler Thromb Vasc Biol. 2006;26(10):2200-7.

33. You T, Yang R, Lyles MF, Gong D, Nicklas BJ. Abdominal adipose tissue cytokine gene expression: relationship to obesity and metabolic risk factors. Am J Physiol Endocrinol Metab. 2005;288(4):E741-7.

34. Kern PA, Saghizadeh M, Ong JM, Bosch RJ, Deem R, Simsolo RB. The expression of tumor necrosis factor in human adipose tissue. Regulation by obesity, weight loss, and relationship to lipoprotein lipase. J Clin Invest. 1995;95(5):2111-9.

35. Stephens JM, Lee J, Pilch PF. Tumor necrosis factor-alpha-induced insulin resistance in 3T3-L1 adipocytes is accompanied by a loss of insulin receptor substrate-1 and GLUT4 expression without a loss of insulin receptor-mediated signal transduction. J Biol Chem. 1997;272(2):971-6.

36. Hauner $H$, Petruschke T, Russ M, Rohrig K, Eckel J. Effects of tumour necrosis factor alpha (TNF alpha) on glucose transport and lipid metabolism of newly-differentiated human fat cells in cell culture. Diabetologia. 1995;38(7):764-71.

37. Maachi M, Pieroni L, Bruckert E, Jardel C, Fellahi S, Hainque B, et al. Systemic low-grade inflammation is related to both circulating and adipose tissue TNFalpha, leptin and IL-6 levels in obese women. Int J Obes Relat Metab Disord. 2004;28(8):993-7.

38. Heliovaara MK, Teppo AM, Karonen SL, Tuominen JA, Ebeling P. Plasma IL-6 concentration is inversely related to insulin sensitivity, and acute-phase proteins associate with glucose and lipid metabolism in healthy subjects. Diabetes Obes Metab. 2005;7(6):729-36

39. Bastard JP, Jardel C, Bruckert E, Blondy P, Capeau J, Laville M, et al. Elevated levels of interleukin 6 are reduced in serum and subcutaneous 
adipose tissue of obese women after weight loss. J Clin Endocrinol Metab. 2000;85(9):3338-42

40. Pachler C, Ikeoka D, Plank J, Weinhandl H, Suppan M, Mader JK, et al. Subcutaneous adipose tissue exerts proinflammatory cytokines after minimal trauma in humans. Am J Physiol Endocrinol Metab. 2007;293(3):E690-6.

41. Rotter V, Nagaev I, Smith U. Interleukin-6 (IL-6) induces insulin resistance in 3T3-L1 adipocytes and is, like IL-8 and tumor necrosis factor-alpha, overexpressed in human fat cells from insulin-resistant subjects. J Biol Chem. 2003;278(46):4577-84.

42. Stith RD, Luo J. Endocrine and carbohydrate responses to interleukin-6 in vivo. Circ Shock. 1994;44(4):210-5.

43. Greenberg AS, Nordan RP, McIntosh J, Calvo JC, Scow RO, Jablons D. Interleukin 6 reduces lipoprotein lipase activity in adipose tissue of mice in vivo and in 3T3-L1 adipocytes: a possible role for interleukin 6 in cancer cachexia. Cancer Res. 1992;52(15):4113-6.

44. Mohamed-Ali V, Goodrick S, Rawesh A, Katz DR, Miles JM, Yudkin JS, et al. Subcutaneous adipose tissue releases interleukin-6, but not tumor necrosis factor-alpha, in vivo. J Clin Endocrinol Metab. 1997;82(12):4196-200.

45. Maeda K, Okubo K, Shimomura I, Funahashi T, Matsuzawa Y, Matsubara K. cDNA cloning and expression of a novel adipose specific collagen-like factor, apM1 (AdiPose Most abundant Gene transcript 1). Biochem Biophys Res Commun. 1996;221(2):286-9.

46. Arita Y, Kihara S, Ouchi N, Takahashi M, Maeda K, Miyagawa J, et al. Paradoxical decrease of an adipose-specific protein, adiponectin, in obesity. Biochem Biophys Res Commun. 1999;257(1):79-83.

47. Cote M, Mauriege P, Bergeron J, Almeras N, Tremblay A, Lemieux I, et al. Adiponectinemia in visceral obesity: impact on glucose tolerance and plasma lipoprotein and lipid levels in men. J Clin Endocrinol Metab. 2005:90(3):1434-9.

48. Stefan N, Vozarova B, Funahashi T, Matsuzawa Y, Weyer C, Lindsay RS, et al. Plasma adiponectin concentration is associated with skeletal muscle insulin receptor tyrosine phosphorylation, and low plasma concentration precedes a decrease in whole-body insulin sensitivity in humans. Diabetes. 2002;51(6): 1884-8.

49. Berg AH, Combs TP, Du X, Brownlee M, Scherer PE. The adipocyte-secreted protein Acrp30 enhances hepatic insulin action. Nat Med. 2001;7(8):947-53.

50. Yamauchi T, Kamon J, Minokoshi Y, Ito Y, Waki H, Uchida S, et al. Adiponectin stimulates glucose utilization and fatty-acid oxidation by activating AMPactivated protein kinase. Nat Med. 2002;8(11):1288-95

51. Ouchi N, Ohishi M, Kihara S, Funahashi T, Nakamura T, Nagaretani H, et al. Association of hypoadiponectinemia with impaired vasoreactivity. Hypertension. 2003;42(3):231-4.

52. Kumada M, Kihara S, Sumitsuji S, Kawamoto T, Matsumoto S, Ouchi N, et al. Association of hypoadiponectinemia with coronary artery disease in men. Arterioscler Thromb Vasc Biol. 2003;23(1):85-9

53. Zoccali C, Mallamaci F, Tripepi G, Benedetto FA, Cutrupi S, Parlongo S, et al. Adiponectin, metabolic risk factors, and cardiovascular events among patients with end-stage renal disease. J Am Soc Nephrol. 2002;13(1):134-41.

54. Maahs DM, Ogden LG, Kinney GL, Wadwa P, Snell-Bergeon JK, Dabelea D, et al. Low plasma adiponectin levels predict progression of coronary artery calcification. Circulation. 2005;111(6):747-53.

55. Mohamed-Ali V, Goodrick S, Bulmer K, Holly JM, Yudkin JS, Coppack SW. Production of soluble tumor necrosis factor receptors by human subcutaneous adipose tissue in vivo. Am J Physiol. 1999;277(6 Pt 1):E971-5.

56. Wellen KE, Hotamisligil GS. Inflammation, stress, and diabetes. J Clin Invest. 2005;115(5):1111-9.

57. Dinarello CA, Wolff SM. The role of interleukin-1 in disease. N Engl J Med. 1993;328(2):106-13

58. Tipping PG, Lowe MG, Holdsworth SR. Glomerular interleukin 1 production is dependent on macrophage infiltration in anti-GBM glomerulonephritis. Kidney Int. 1991;39(1):103-10.

59. Major CD, Wolf BA. Interleukin-1 beta stimulation of c-Jun $\mathrm{NH}(2)$-terminal kinase activity in insulin-secreting cells: evidence for cytoplasmic restriction. Diabetes. 2001;50(12):2721-8.

60. De Benedetti F, Pignatti P, Massa M, Sartirana P, Ravelli A, Martini A. Circulating levels of interleukin 1 beta and of interleukin 1 receptor antagonist in systemic juvenile chronic arthritis. Clin Exp Rheumatol. 1995;13(6):779-84.

61. Van Deuren M, Van der Ven-Jongekrijg J, Demacker PN, Bartelink AK, Van Dalen R, Sauerwein RW, et al. Differential expression of proinflammatory cytokines and their inhibitors during the course of meningococcal infections. J Infect Dis. 1994;169(1):157-61

62. Beutler BA, Cerami A. Recombinant interleukin 1 suppresses lipoprotein lipase activity in 3T3-L1 cells. J Immunol. 1985;135(6):3969-71.

63. Juge-Aubry CE, Somm E, Chicheportiche R, Burger D, Pernin A, Cuenod-Pittet $B$, et al. Regulatory effects of interleukin (IL)-1, interferon-beta, and IL-4 on the production of IL-1 receptor antagonist by human adipose tissue. J Clin Endocrinol Metab. 2004;89(6):2652-8.

64. Matsuki T, Horai R, Sudo K, Iwakura Y. IL-1 plays an important role in lipid metabolism by regulating insulin levels under physiological conditions. J Exp Med. 2003;198(6):877-88.
65. Gerszten RE, Garcia-Zepeda EA, Lim YC, Yoshida M, Ding HA, Gimbrone MA, Jr., et al A. MCP-1 and IL-8 trigger firm adhesion of monocytes to vascular endothelium under flow conditions. Nature. 19992:398(6729):718-23.

66. Straczkowski M, Kowalska I, Nikolajuk A, Dzienis-Straczkowska S, Szelachowska M, Kinalska I. Plasma interleukin 8 concentrations in obese subjects with impaired glucose tolerance. Cardiovasc Diabetol. 2003;2(1):5.

67. Murdolo G, Hammarstedt A, Sandqvist M, Schmelz M, Herder C, Smith U, et al. Monocyte chemoattractant protein-1 in subcutaneous abdominal adipose tissue: characterization of interstitial concentration and regulation of gene expression by insulin. J Clin Endocrinol Metab. 2007;92(7):2688-95.

68. Kamei N, Tobe K, Suzuki R, Ohsugi M, Watanabe T, Kubota N, et al. Overexpression of monocyte chemoattractant protein-1 in adipose tissues causes macrophage recruitment and insulin resistance. J Biol Chem. 2006;281(36):26602-14.

69. Sartipy P, Loskutoff DJ. Monocyte chemoattractant protein 1 in obesity and insulin resistance. Proc Natl Acad Sci USA. 2003;100(12):7265-70.

70. Kanda H, Tateya S, Tamori Y, Kotani K, Hiasa K, Kitazawa R, et al. MCP-1 contributes to macrophage infiltration into adipose tissue, insulin resistance, and hepatic steatosis in obesity. J Clin Invest. 2006;116(6):1494-505.

71. Juge-Aubry CE, Somm E, Pernin A, Alizadeh N, Giusti V, Dayer JM, et al. Adipose tissue is a regulated source of interleukin-10. Cytokine. 2002;29(6):270-4.

72. Esposito K, Pontillo A, Giugliano F, Giugliano G, Marfella R, Nicoletti G, et al. Association of low interleukin-10 levels with the metabolic syndrome in obese women. J Clin Endocrinol Metab. 2003:88(3):1055-8.

73. Straczkowski M, Kowalska I, Nikolajuk A, Krukowska A, Gorska M. Plasma interleukin-10 concentration is positively related to insulin sensitivity in young healthy individuals. Diabetes Care. 2005;28(8):2036-7.

74. Bradley RL, Fisher FF, Maratos-Flier E. Dietary fatty acids differentially regulate production of TNF-alpha and IL-10 by murine 3T3-L1 adipocytes. Obesity. 2008;16(5):938-44

75.Gomez-Ambrosi J, Fruhbeck G. Evidence for the involvement of resistin in inflammation and cardiovascular disease. Curr Diabetes Rev. 2005;1(3):227-34.

76. Sethi JK, Vidal-Puig A. Visfatin: the missing link between intra-abdominal obesity and diabetes? Trends Mol Med. 2005;11(8):344-7.

77. Zhang Y, Proenca R, Maffei M, Barone M, Leopold L, Friedman JM. Positional cloning of the mouse obese gene and its human homologue. Nature. 1994;372(6505):425-32.

78. Faroogi IS, Matarese G, Lord GM, Keogh JM, Lawrence E, Agwu C, et al. Beneficial effects of leptin on obesity, T cell hyporesponsiveness, and neuroendocrine/ metabolic dysfunction of human congenital leptin deficiency. J Clin Invest. 2002;110(8):1093-103

79. Farooqi IS, ORahilly S. Leptin: a pivotal regulator of human energy homeostasis. Am J Clin Nutr. 2009;89(3):980S-4S

80. Heymsfield SB, Greenberg AS, Fujioka K, Dixon RM, Kushner R, Hunt T, et al. Recombinant leptin for weight loss in obese and lean adults: a randomized, controlled, dose-escalation trial. JAMA. 1999;282(16):1568-75.

81. Schwartz MW, Prigeon RL, Kahn SE, Nicolson M, Moore J, Morawiecki A, et al. Evidence that plasma leptin and insulin levels are associated with body adiposity via different mechanisms. Diabetes Care. 1997;20(9):1476-81.

82. Takahashi M, Funahashi T, Shimomura I, Miyaoka K, Matsuzawa Y. Plasma leptin levels and body fat distribution. Horm Metab Res. 1996;28(12):751-2.

83. Gao Z, Zhang X, Zuberi A, Hwang D, Quon MJ, Lefevre M, et al. Inhibition of insulin sensitivity by free fatty acids requires activation of multiple serine kinases in 3T3-L1 adipocytes. Mol Endocrinol. 2004;18(8):2024-34.

84. Gustafson B, Hammarstedt A, Andersson CX, Smith U. Inflamed adipose tissue: a culprit underlying the metabolic syndrome and atherosclerosis. Arterioscler Thromb Vasc Biol. 2007;27(11):2276-83.

85. Kofler S, Nickel T, Weis M. Role of cytokines in cardiovascular diseases: a focus on endothelial responses to inflammation. Clin Sci (Lond). 2005;108(3):205-13.

86. Bhagat K, Vallance P. Inflammatory cytokines impair endothelium-dependent dilatation in human veins in vivo. Circulation. 1997;96(9):3042-7.

87. Ross R. Atherosclerosis--an inflammatory disease. N Engl J Med. 1999;340(2):115-26.

88. Mantovani A, Garlanda C, Introna M, Vecchi A. Regulation of endothelial cell function by pro- and anti-inflammatory cytokines. Transplant Proc. 1998;30(8):4239-43.

89. Foster-Schubert KE, Cummings DE. Emerging therapeutic strategies for obesity. Endocr Rev. 2006;27(7):779-93.

90. Hansen EN, Torquati A, Abumrad NN. Results of bariatric surgery. Annu Rev Nutr. 2006;26:481-511.

91. Okuno A, Tamemoto H, Tobe K, Ueki K, Mori Y, Iwamoto K, et al. Troglitazone increases the number of small adipocytes without the change of white adipose tissue mass in obese Zucker rats. J Clin Invest. 1998;101(6):1354-61.

Artigo recebido: 28/07/09

Aceito para publicação: 8/09/09 